\title{
Evaluation of Pre-Mixture Insecticide, Sulfoxaflor 3.75 + Chlorpyriphos 37.5 SE against Ear Head Bug, Leptocorisa acuta and Combinational Evaluation with Other Insecticides, Fungicides and Urea in Rice
}

\author{
V. Amsagowri* and N. Muthukrishnan \\ Tamil Nadu Agricultural University, Coimbatore, India \\ *Corresponding author
}

\section{Keywords}

Rice, Earhead bug, Sulfoxaflor $3.75+$ chlorpyriphos 37.5 SC, Tank mix, Funigicides

Article Info

\section{Accepted:}

17 January 2021

Available Online:

10 February 2021

\section{A B S T R A C T}

Leptocorisa acuta Thunberg (Hemiptera: Coreidae) is an important and common pest of rice which is also as called ear head bug. The present experiment was carried out to determine the relative efficacy of newer pre-mixture insecticides and also combination with other insecticides, fungicides and urea were carried out at Agricultural College and Research Institute, Madurai, TNAU during 2012 and 2013. In the first experiment, among the treatments, minimum earhead bug populations (1.6/hill) was recorded in the treatment comprising of the new combination product of Sulfoxaflor 3.75 + chlorpyriphos 37.5 SC @619 g a.i/haand it was on par with Sulfoxaflor 3.75 + chlorpyriphos 37.5 SC @ $516 \mathrm{~g}$ a.i./ha followed by sulfoxaflor 24 SC @ $75 \mathrm{~g}$ a.i/ha. In the second experiment, Sulfoxaflor 3.75 + chlorpyriphos 37.5 SE $619 \mathrm{~g}+$ thiamethoxam 25 WG $25 \mathrm{~g}$ followed sulfoxaflor 3.75 + chlorpyriphos 37.5 SE $619 \mathrm{~g}+$ monocrotophos 36 WSL 360 ga.i/ha, and sulfoxaflor 3.75 + chlorpyriphos $37.5619 \mathrm{~g}$ a.i/ha+ urea $2 \%$ tank mix were found effective in reducing the ear head bug population. Sulfoxaflor 3.75 + chlorpyriphos 37.5 SE mixtures with other insecticides, fungicides and urea did not show any phytoxicity on rice plants.

\section{Introduction}

Rice is an important crop of the world. It is staple food for more than $60 \%$ of worlds' population. Worldwide this crop is grown over acreage of around 167.25 million hectares (Shahbandeh, 2019). In rice cultivation, only Asia accounts for about $90 \%$ of world's rice in area and production. Among the rice growing countries, India has largest area under rice in the world i.e., $28 \%$ of the world's area of production, and ranks second to the China (Tiwari et al., 2014).

The rice plant is attacked by more than 100 species of insects and 20 of them can cause serious economic loss. Insect pests like stem borer (SB), leaf folder (LF), rice skipper 
(SKP), gall midge (GM), gundhi bug (GB), brown plant hopper $(\mathrm{BPH})$ white-backed plant and hopper (WBPH) cause serious damage to rice crop which is responsible for reducing rice yield.

Among the pest, Rice gundhi bug, Leptocorisa acuta (Thumb) is an important pest of rice (Rao and Prakash, 1995). The nymphs and adult of rice bug causes damage by feeding on the sap of milky grain and turns them chaffy.

Rice gundhi bug is one of the serious pests of rice in India and sometimes reduce yield by as much as $30 \%$. Chemical control is still considered as the first line of defense in rice pest control. Hence, timely application of insecticides is the most commonly used measure for reducing pest population and sometimes the only practical solution to sudden outbreaks of insect pests in general.

Thus it is vital that alternate insecticides be explored for managing the pests. New molecules will be searched in the context of effective against rice ear head bug as well as eco-friendly, selective, cost effective, biodegradable, and safe to natural enemies and non-target organisms.

\section{Materials and Methods}

Field evaluation of sulfoxaflor $3.75+$ chlorpyriphos 37.5 SE against ear head bug

Two field experiments with eight treatments and three replications in randomized block design (RBD) were laid out to evaluate the efficacy of sulfoxaflor 3.75 + chlorpyriphos 37.5 SE against ear head bug, L. acutaon rice (cv. Seeraga samba) at A block of AC\&RI, Madurai and in a farmer's holding at Kallandhiri village, Melur Block of Madurai District in two consecutive seasons of 2012 to 2013 respectively. The plot size was $5 \times 5 \mathrm{~m}^{2} /$ treatment which occupied 63number of rice plants. TNAU recommended agronomic practices were followed to maintain healthy rice plants throughout experimental period.

Sulfoxaflor 3.75 + chlorpyriphos 37.5 SE was assessed @413 g a.i./ha (1000 ml/ha), 516 g a.i./ha (1250 ml/ha) and $619 \mathrm{~g}$ a.i./ha (1500 $\mathrm{ml} / \mathrm{ha}$ ) and compared with sulfoxaflor $24 \mathrm{SC}$ @ $75 \mathrm{~g}$ a.i./ha $(313 \mathrm{ml} / \mathrm{ha})$, chlorpyriphos 20 EC @ $375 \mathrm{~g}$ a.i./ha (1875 ml/ha), chlorantraniliprole 20 SE @ $30 \mathrm{~g}$ a.i./ha (150 mi/ha), buprofezin 25 EC @200 g a.i./ha (800 $\mathrm{ml} / \mathrm{ha}$ ) and untreated check.

Field evaluation of sulfoxaflor $3.75 \%+$ chlorpyriphos $37.5 \%$ SE mixtureswith other insecticides, fungicides and urea against ear head bug

Two field experiments with 12 treatments and three replications in randomized block design(RBD) were laid out to study the compatibility of sulfoxaflor $3.75+$ chlorpyriphos37.5 SE+ quinalphos $25 \mathrm{EC}$ (619 $\mathrm{g}$ a.i./ha +375 g a.i./ha); sulfoxaflor $3.75+$ chlorpyriphos $37.5 \mathrm{SE}+$ quinalphos $25 \mathrm{EC}$ (309 g a.i./ha + $190 \mathrm{~g}$ a.i./ha); sulfoxaflor 3.75 + chlorpyriphos 37.5 SE + monocrotophos 36 SC (619 g a.i./ha +360 g a.i./ha); sulfoxaflor $3.75+$ chlorpyriphos $37.5 \quad \mathrm{SE}+$ monocrotophos $36 \mathrm{SC}$ (309 g a.i./ha + $180 \mathrm{~g}$ a.i./ha); sulfoxaflor 3.75 + chlorpyriphos 37.5 $\mathrm{SE}+$ thiamethoxam $25 \mathrm{WG}(619 \mathrm{~g}$ a.i./ha +25 g a.i./ha); sulfoxaflor 3.75 + chlorpyriphos 37.5 SE+ thiamethoxam $25 \mathrm{WG}$ (309 g a.i./ha $+12.5 \mathrm{~g}$ a.i./ha); sulfoxaflor $3.75+$ chlorpyriphos 37.5 SE+ carbendazim 50 WP (619 g a.i./ha $+250 \mathrm{~g}$ a.i./ha); sulfoxaflor 3.75 + chlorpyriphos 37.5 SE + carbendazim 50 WP (309 g a.i./ha + $125 \mathrm{~g}$ a.i./ha); sulfoxaflor 3.75 + chlorpyriphos $37.5 \mathrm{SE}+$ tricyclazole 75 WP (619 g a.i./ha + $125 \mathrm{~g}$ a.i./ha); sulfoxaflor 3.75 + chlorpyriphos $37.5 \mathrm{SE}+$ tricyclazole 75 WP (309 g a.i./ha + $63 \mathrm{~g}$ a.i./ha); sulfoxaflor 3.75 + chlorpyriphos 37.5 SE+ urea (619 g a.i./ha $+2 \%$ ); and untreated control against ear 
head bug on rice on rice (cv. Seeraga samba) at A block of AC\&RI, Madurai and in a farmer's holding at Kallandhiri village of Madurai district in two consecutive seasons of 2012 to 2013 . The plot size was $5 \times 5 \mathrm{~m}^{2} /$ treatment which occupied 63 number of rice plants.

Healthy crop stand was maintained throughout the experimental period by following TNAU recommended agronomic practices. In all the experiments, there were three replications and two applications at 15-20 days interval based on the economic threshold level (ETL) of target pests from 30 days after transplantation. The spray fluid used was 500-700 1/ha based on the age of the crop. Insecticides were sprayed to run off point using a high volume hand operated knapsack sprayer with hydraulic cone nozzle. Care was also taken to avoid spray drifts to adjacent plots.

Effect of sulfoxaflor 3.75 + chlorpyriphos 37.5 SE on the damage of $L$. acutaand their natural enemies on ricewere assessed as indicated below.

\section{Assessment of population of L.acuta}

Population of nymphs and adults of L. acuta per plant was recorded from 10 randomly selected plants on pre-treatment, 7, 10 and 15 days after treatment (DAT) after $2^{\text {nd }}$ and $3^{\text {rd }}$ spray.

\section{Results and Discussion}

\section{Effect of sulfoxaflor 3.75 + chlorpyriphos 37.5 SE against L. acuta}

Effect of sulfoxaflor 3.75 + chlorpyriphos 37.5 SE on the population of EHB was observed only after second spray. Number of nymphs and adults of L. acuta varied from 4.6 to 5.2per hill before imposing treatments (Table 1). There was significant reduction in the EHB population due to treatments at 7,10 and 15 DAT after second spray due to sulfoxaflor 3.75 + chlorpyriphos 37.5 SE 619 and 516 ga.i./ha doses $(2.2$ and 2.8 /hill at 7 DAT; 1.6 and $1.9 /$ hill on 10 DAT and 0.9 and $1.2 /$ hill on 15 DAT) respectively when compared to the population of $6.3,8.5$ and 12.0 per hill at 7,10 and 15 DAT respectively onthe untreated plot. Sulfoxaflor 24SC $75 \mathrm{~g}$ a.i./ha, sulfoxaflor 3.75 + chlorpyriphos 37.5 SE413 ga.i./ha, buprofezin 25 SC $200 \mathrm{~g}$ a.i./ha, chlorantraniliprole $\quad 30 \quad \mathrm{~g}$ a.i/ha and chlorpyriphos 20 EC $375 \mathrm{~g}$ a.i./ha, however registered the population of $3.4,3.7,4.1,4.8$ and 4.9 per hill at 7 DAT; 2.4, 2.9, 3.6, 4.1 and 4.7 per hill at 10 DAT and 1.9, 2.4,3.0, 3.3 and 3.9 per hill at 15 DAT.

At 7 DAT after third spray sulfoxaflor $3.75+$ chlorpyriphos 37.5 SE 619 and 516 ga.i./ha significantly reduced EHB population to 2.2 and 2.7 per hill, respectively.

The next best treatments were sulfoxaflor 75 ga.i./ha (3.2/hill), sulfoxaflor $3.75+$ chlorpyriphos 37.5 SE413 ga.i./ha (3.6/hill), buprofezin 25 SC $200 \mathrm{~g}$ a.i./ha (4.9/hill), chlorantraniliprole 30 ga.i./ha (5.6/hill) and chlorpyriphos 20 EC $375 \mathrm{~g}$ a.i./ha (5.2/hill) as against untreated check (7.5/hill). At 10 DAT, minimum EHB population was recorded in plots sprayed with sulfoxaflor $3.75+$ chlorpyriphos 37.5 SE619 ga.i./ha (1.6/hill) and sulfoxaflor 3.75 + chlorpyriphos 37.5 SE516 ga.i./ha (2.0/hill).

The next effective treatments were sulfoxaflor 24 SC 75 g a.i./ha (2.6/hill), sulfoxaflor $3.75+$ chlorpyriphos 37.5 SE 413 g a.i./ha (2.8/hill) and buprofezin 25 SC $200 \mathrm{~g}$ a.i.ha (3.7/hill) followed by chlorantraniliprole 20 SC $30 \mathrm{~g}$ a.i./ha (4.1/hill) and chlorpyriphos 20 EC 375 g a.i/ha (4.7/hill). The same trend was followed after At 15 DAT. Mean data revealed that number of EHB ranged from 1.6 to 4.5 per hill due to treatments. Sulfoxaflor $3.75+$ 
chlorpyriphos 37.5 SE619 g and 513 ga.i./ha were significantly superior and registered the lowest EHB population of $1.6 \quad(85.7 \%$ reduction) and 2.0 (82.1\% reduction) per hill, respectively.

This was followed by sulfoxaflor24 SC 75 ga.i./ha, sulfoxaflor 3.75 + chlorpyriphos 37.5 SE413 ga.i./ha, buprofezin 25 SC $200 \mathrm{~g}$ a.i./ha and chlorantraniliprole $20 \mathrm{SC} 30 \mathrm{~g}$ a.i./ha which registered 2.6, 3.0, 3.7 and 4.2 EHB population per hill and 76.8, 73.2, 67.0 and 62.5 per cent reduction respectively.

Chlorpyriphos 20 EC 375 g a.i./ha contributed moderate reduction in the EHB population (4.5/hill with $59.8 \%$ reduction). The highest population of EHB recorded in untreated control (11.2/hill).

These results are in accordance with the findings of Lysandrou et al., (2010) reported that sulfoxaflor 24 SC @ 36 per ha provided very good control at 10 days and sulfoxaflor 500WDG demonstrated very robust short-term and residual activity when applied @ 25-50 g a.i. per ha, thusclearly exhibited consistent performance against Amrascadevastansand proved as an excellent new tool for managing the most destructive hemipteranpests.

Siebert et al.,(2012) also indicated that sulfoxaflor applied at $\geq 50 \mathrm{~g}$ a.i. per ha provided good control and yield levels similar to that observed with acephate against tarnished plant bug. Indoxacarb 10 +Thiamethoxam 10 WG @ 50 +50g a.i./ha was found most effective against gundhi bug (Mohanta et al., 2020).

New combination product of Spinetoram 6SC+ Methoxyfenozide 30 SC @ 400ml/ha recorded minimum earhead bug population and it was at par with spinetoram $6 \mathrm{SC}+$ methoxyfenozide 30 SC @ $375 \mathrm{ml} / \mathrm{ha}$, flubendiamide 48 SC @ 50 ml/ha (Kumari et al., 2020). Similarly, emamectin benzoate 5 WSG $0.015 \%$ @ $3 \mathrm{gm} /$ litre was found the most effective in controlling rice gundhibug and it was at par with the treatment of imidacloprid 17.8 SL 0.05\% @ 3 ml/10 litres (Ghoghari et al., 2019).

\section{Effect of sulfoxaflor 3.75 + chlorpyriphos 37.5 SE mixtures on ear head bug population, L. acuta.}

The effect of sulfoxaflor 3.75 + chlorpyriphos 37.5 SE mixtures on EHB population before imposing treatments ranged from 5.0 to 5.6 /hill (Table 2).

After the second application of sulfoxaflor 3.75 + chlorpyriphos 37.5 SE combinations, there was significant reduction on EHB population when compared to untreated check.

At 7 DAT, sulfoxaflor 3.75 + chlorpyriphos 37.5 SE $619 \mathrm{~g}$ a.i/ha in combination with thiamethoxam 25 WG 25 ga.i/ha,quinalphos 25 EC 375 ga.i/ha, monocrotophos36 WSL 360 g,a.i/hacarbendazim50 WP 250 ga.i/ha, tricyclazole75 WP 375 ga.i/ha and urea 2\% treated plots recorded the population range from 2.7 to 3.1per hill, while the higher population was noticed in sulfoxaflor $3.75+$ chlorpyriphos 37.5 SE $309 \mathrm{~g}$ a.i/ha in combination with thiamethoxam25 WG 12.5 g, quinalphos25 EC $190 \mathrm{~g}$, monocrotophos36 WSL $180 \mathrm{~g}$, carbendazim50 WP $250 \mathrm{~g}$ and tricyclazole75 WP $190 \mathrm{~g}$ treated plots, which recorded the population range from 4.2 to 5.8 per hill as against untreated control (7.4/hill). The same trend of population reduction was followed at 10 and15 DAT after second spray.

After the third application of sulfoxaflor 3.75 + chlorpyriphos 37.5 SE combinations there was significant reduction on EHB population when compared to untreated check. 
Table.1 Effect of sulfoxaflor 3.75 + chlorpyriphos SE against Leptocorisa acuta on rice - Pooled data (2012 \&2013)

\begin{tabular}{|c|c|c|c|c|c|c|c|c|c|}
\hline \multirow{3}{*}{$\begin{array}{l}\text { Treatments } \\
\text { (a.i./ha) }\end{array}$} & \multicolumn{7}{|c|}{ Number of nymphs and adults/hill on DAT } & \multirow{3}{*}{$\begin{array}{c}\text { Mean } \\
\text { population } \\
\text { of nymphs } \\
\text { and adults }\end{array}$} & \multirow{3}{*}{$\begin{array}{l}\text { Per cent } \\
\text { reduction } \\
\text { over } \\
\text { control }\end{array}$} \\
\hline & \multirow{2}{*}{$\begin{array}{l}\text { Pre } \\
\text { count }\end{array}$} & \multicolumn{3}{|c|}{$2^{\text {nd }}$ spray } & \multicolumn{3}{|c|}{$3^{\text {rd }}$ spray } & & \\
\hline & & 7 & 10 & 15 & 7 & 10 & 15 & & \\
\hline $\begin{array}{c}\text { Sulfoxaflor } 3.75+ \\
\text { chlorpyriphos37.5 SE413 g }\end{array}$ & 4.6 & $3.7^{\mathrm{c}}$ & $2.9^{\mathrm{c}}$ & $2.4^{\mathrm{bc}}$ & $3.6^{\mathrm{c}}$ & $2.8^{\mathrm{d}}$ & $2.3^{\mathrm{c}}$ & $3.0^{\mathrm{d}}$ & 73.2 \\
\hline $\begin{array}{c}\text { Sulfoxaflor } 3.75 \\
+ \text { +chlorpyriphos37.5 SE516 g }\end{array}$ & 4.7 & $2.8^{\mathrm{b}}$ & $1.9^{\mathbf{b}}$ & $1.2^{\mathrm{a}}$ & $2.7^{\mathbf{b}}$ & $2.0^{\mathbf{b}}$ & $1.4^{\mathrm{b}}$ & $2.0^{b}$ & 82.1 \\
\hline $\begin{array}{l}\text { Sulfoxaflor } 3.75 \\
\text { +chlorpyriphos37.5 SE } 619 \mathrm{~g}\end{array}$ & 4.9 & $2.2^{\mathrm{a}}$ & $1.6^{\mathrm{a}}$ & $0.9^{\mathrm{a}}$ & $2.2^{\mathrm{a}}$ & $1.6^{\mathrm{a}}$ & $0.9^{\mathrm{a}}$ & $1.6^{\mathrm{a}}$ & 85.7 \\
\hline Sulfoxaflor 24 SC $75 \mathrm{~g}$ & 5.2 & $3.4^{\mathrm{b}}$ & $2.4^{\mathrm{b}}$ & $1.9^{\mathrm{a}}$ & $3.2^{\mathbf{b}}$ & $2.6^{\mathbf{c}}$ & $1.9^{\mathbf{c}}$ & $2.6^{\mathrm{c}}$ & 76.8 \\
\hline Chlorpyriphos 20 EC 375 g & 5.0 & $4.9^{\mathrm{d}}$ & $4.7^{\mathrm{e}}$ & $3.9^{\text {ab }}$ & $5.2^{\mathrm{e}}$ & $4.7^{\mathrm{g}}$ & $3.9^{\mathrm{e}}$ & $4.5^{\mathrm{g}}$ & 59.8 \\
\hline $\begin{array}{c}\text { Chlorantraniliprole } 20 \text { SC } 30 \\
\text { g }\end{array}$ & 5.1 & $4.8^{\mathrm{d}}$ & $4.1^{d}$ & $3.3^{\mathrm{ab}}$ & $5.6^{\mathrm{e}}$ & $4.1^{\mathrm{f}}$ & $3.6^{\mathrm{e}}$ & $4.2^{\mathrm{f}}$ & 62.5 \\
\hline Buprofezin 25 SC $200 \mathrm{~g}$ & 4.7 & $4.1^{\mathrm{c}}$ & $3.6^{\mathrm{c}}$ & $3.0^{\mathbf{a b}}$ & $4.9^{d}$ & $3.7^{\mathrm{e}}$ & $3.1^{d}$ & $3.7^{\mathrm{e}}$ & 67.0 \\
\hline Untreated control & 5.0 & $6.9^{\mathrm{e}}$ & $8.9^{f}$ & $12.2^{\mathrm{c}}$ & $7.5^{\mathrm{f}}$ & $9.0^{\mathrm{h}}$ & $12.3^{\mathrm{f}}$ & $11.2^{\mathrm{h}}$ & - \\
\hline CD $(0.05)$ & - & 0.10 & 0.12 & 0.66 & 0.10 & 0.09 & 0.13 & 0.06 & - \\
\hline SEd & - & 0.04 & 0.06 & 0.57 & 0.05 & 0.04 & 0.06 & 0.03 & - \\
\hline
\end{tabular}

Data are mean values of three replications.

Values were transformed by square root transformation and the original values are given.

Means with columns lacking common bold upper case superscript are significantly different $(\mathrm{P}<0.05)$. 
Table.2 Effect of sulfoxaflor 3.75 + chlorpyriphos 37.5 SE mixtures against Leptocorisa acuta on rice - Pooled data (2012 \&2013)

\begin{tabular}{|c|c|c|c|c|c|c|c|c|c|}
\hline \multirow{3}{*}{$\begin{array}{l}\text { Treatments } \\
\text { (a.i./ha) }\end{array}$} & \multicolumn{7}{|c|}{ Number of nymphs and adults/hill on DAT } & \multirow{3}{*}{$\begin{array}{c}\text { Mean } \\
\text { population } \\
\text { of nymphs } \\
\text { and adults }\end{array}$} & \multirow{3}{*}{$\begin{array}{c}\text { Per cent } \\
\text { reduction } \\
\text { over } \\
\text { control }\end{array}$} \\
\hline & \multirow{2}{*}{$\begin{array}{l}\text { Pre } \\
\text { count }\end{array}$} & \multicolumn{3}{|c|}{$2^{\text {nd }}$ spray } & \multicolumn{3}{|c|}{$3^{\text {rd }}$ spray } & & \\
\hline & & 7 & 10 & 15 & 7 & 10 & 15 & & \\
\hline $\begin{array}{c}\text { Sulfoxaflor } 3.75 \text { + chlorpyriphos } 37.5 \mathrm{SE} 619 \mathrm{~g}+ \\
\text { quinalphos } 25 \mathrm{EC} 375 \mathrm{~g}\end{array}$ & 5.1 & $2.5^{b}$ & $1.6^{\mathrm{ab}}$ & $0.7^{\mathrm{a}}$ & $2.7^{\mathrm{b}}$ & $1.4^{\mathrm{b}}$ & $0.6^{\mathrm{b}}$ & $1.6^{\mathrm{b}}$ & 84.3 \\
\hline $\begin{array}{c}\text { Sulfoxaflor } 3.75 \text { + chlorpyriphos } 37.5 \mathrm{SE} 309 \mathrm{~g}+ \\
\text { quinalphos } 25 \mathrm{EC} 190 \mathrm{~g}\end{array}$ & 5.5 & $4.2^{d}$ & $3.9^{\text {bcd }}$ & $3.0^{\mathrm{e}}$ & $4.6^{\mathrm{b}}$ & $4.1^{\mathrm{e}}$ & $3.4^{\mathrm{e}}$ & $3.9^{f}$ & 61.8 \\
\hline $\begin{array}{c}\text { Sulfoxaflor } 3.75 \text { + chlorpyriphos } 37.5 \text { SE } 619 \mathrm{~g}+ \\
\text { monocrotophos } 36 \text { WSL } 360 \mathrm{~g}\end{array}$ & 5.0 & $2.6^{\mathrm{c}}$ & $1.4^{\mathbf{a b}}$ & $0.7^{\mathbf{a b}}$ & $2.3^{\mathrm{a}}$ & $1.4^{\mathrm{a}}$ & $1.0^{\mathrm{c}}$ & $1.5^{\mathrm{ab}}$ & 85.3 \\
\hline $\begin{array}{c}\text { Sulfoxaflor } 3.75 \text { + chlorpyriphos } 37.5 \mathrm{SE} 309 \mathrm{~g}+ \\
\text { monocrotophos } 36 \mathrm{WSL} 180 \mathrm{~g}\end{array}$ & 5.6 & $4.2^{d}$ & $3.5^{\text {bed }}$ & $2.0^{\mathrm{e}}$ & $4.0^{\mathrm{c}}$ & $3.1^{d}$ & $2.7^{\mathrm{e}}$ & $3.2^{\mathrm{e}}$ & 68.6 \\
\hline $\begin{array}{c}\text { Sulfoxaflor } 3.75 \text { + chlorpyriphos } 37.5 \text { SE } 619 \mathrm{~g}+ \\
\text { thiamethoxam } 25 \text { WG } 25 \mathrm{~g}\end{array}$ & 5.3 & $2.2^{a}$ & $1.0^{\mathrm{a}}$ & $0.6^{a}$ & $2.3^{\mathrm{a}}$ & $1.2^{\mathrm{a}}$ & $0.6^{\mathrm{a}}$ & $1.3^{\mathrm{a}}$ & 87.2 \\
\hline $\begin{array}{c}\text { Sulfoxaflor } 3.75 \text { + chlorpyriphos } 37.5 \text { SE } 309 \mathrm{~g}+ \\
\text { thiamethoxam } 25 \text { WG } 12.5 \mathrm{~g}\end{array}$ & 5.3 & $4.2^{d}$ & $3.8^{\mathbf{b c d}}$ & $2.8^{\mathrm{e}}$ & $4.5^{\mathrm{d}}$ & $3.8^{d}$ & $3.2^{\mathrm{e}}$ & $3.7^{\mathrm{e}}$ & 63.7 \\
\hline $\begin{array}{c}\text { Sulfoxaflor } 3.75 \text { + chlorpyriphos } 37.5 \text { SE } 619 \mathrm{~g}+ \\
\text { carbendazim 50 WP } 250 \mathrm{~g}\end{array}$ & 5.1 & $2.8^{c}$ & $2.0^{d}$ & $1.0^{\mathbf{b c}}$ & $2.8^{\mathrm{b}}$ & $2.0^{c}$ & $1.2^{c}$ & $2.0^{\mathrm{cd}}$ & 80.4 \\
\hline $\begin{array}{c}\text { Sulfoxaflor } 3.75 \text { + chlorpyriphos } 37.5 \text { SE } 309 \text { g + } \\
\text { carbendazim 50 WP } 125 \text { g }\end{array}$ & 5.6 & $5.6^{\mathrm{e}}$ & $4.9^{\text {cd }}$ & $4.3^{f}$ & $5.4^{\mathrm{e}}$ & $5.1^{\mathrm{f}}$ & $4.0^{f}$ & $4.8^{\mathrm{g}}$ & 52.9 \\
\hline $\begin{array}{l}\text { Sulfoxaflor } 3.75 \text { + chlorpyriphos } 37.5 \text { SE } 619 \mathrm{~g}+ \\
\text { tricyclazole } 75 \text { WP } 375 \mathrm{~g}\end{array}$ & 5.5 & $3.1^{\mathrm{c}}$ & $2.0^{\mathbf{a b c}}$ & $1.3^{\mathrm{d}}$ & $2.8^{\mathrm{b}}$ & $1.9^{c}$ & $1.4^{\mathrm{d}}$ & $2.1^{d}$ & 79.4 \\
\hline $\begin{array}{c}\text { Sulfoxaflor } 3.75 \text { + chlorpyriphos } 37.5 \mathrm{SE} 309 \mathrm{~g}+ \\
\text { tricyclazole } 75 \mathrm{WP} 190 \mathrm{~g}\end{array}$ & 5.2 & $5.8^{\mathrm{e}}$ & $5.2^{\mathrm{d}}$ & $5.1^{f}$ & $5.4^{\mathrm{e}}$ & $5.1^{\mathrm{f}}$ & $4.5^{\mathrm{f}}$ & $5.1^{\mathrm{h}}$ & 50.0 \\
\hline $\begin{array}{c}\text { Sulfoxaflor } 3.75+\text { chlorpyriphos } 37.5619 \mathrm{~g}+\text { urea } \\
2 \%\end{array}$ & 5.1 & $2.7^{\mathbf{b c}}$ & $1.8^{\mathbf{b c}}$ & $1.1^{\mathrm{cd}}$ & $2.7^{\mathrm{b}}$ & $1.9^{c}$ & $1.0^{b c}$ & $1.8^{\mathrm{c}}$ & 82.3 \\
\hline Untreated control & 5.0 & $7.4^{\mathrm{f}}$ & $10.5^{\mathrm{e}}$ & $13.5^{\mathrm{g}}$ & $8.1^{\mathrm{f}}$ & $11.4^{\mathrm{g}}$ & $13.1^{\mathrm{g}}$ & $10.2^{\mathrm{i}}$ & - \\
\hline CD (0.05) & - & 0.08 & 0.08 & 0.19 & 0.09 & 0.09 & 0.19 & 0.06 & \\
\hline SEd & - & 0.04 & 0.04 & 0.06 & 0.04 & 0.04 & 0.09 & 0.03 & \\
\hline
\end{tabular}

Data are mean values of three replications.

Values were transformed by square root transformation and the original values are given.

Means with columns lacking common bold upper case superscript are significantly different $(\mathrm{P}<0.05)$. 
At 7 DAT, the lowest EHB population was recorded in plots sprayed with sulfoxaflor3.75 + chlorpyriphos $37.5619 \mathrm{~g}$ a.i./ha in combination with thiamethoxam 25 WG $25 \mathrm{~g}$, monocrotophos 36 WSL 360g, quinalphos 25 EC 375ga.i/ha, carbendazim 50 WP 250 ga.i/ha, tricyclazole75 WP 375 ga.i/ha and urea $2 \%$ which recorded the population range from 2.3 to 2.8 per hill, while the higher larval population per plant was observed in the plots treated with sulfoxaflor 3.75 + chlorpyriphos 37.5 SE309 ga.i./ha combination with thiamethoxam25 WG 12.5 ga.i/ha (4.5/hill), monocrotophos36 WSL 180g (4.0/hill), quinalphos25 EC 190ga.i/ha (4.6/hill), carbendazim50 WP $250 \mathrm{~g}$ a.i/ha (5.4/hill) and tricyclazole75 WP 190ga.i/ha (5.4/hill) as against untreated control (8.1/hill). The same trend of population reduction was followed at 10 and15 DAT after third spray.

Mean data indicated that EHB nymphs and adults ranged from 1.0 to 4.9 per hill due to all treatments. Sulfoxaflor 3.75 + chlorpyriphos 37.5 SE619 ga.i./ha in combination with thiamethoxam 25 WG 25 ga.i/ha, monocrotophos36 WSL 360 ga.i/ha,quinalphos25 EC 375 ga.i/ha, carbendazim50 WP 250 ga.i/ha, tricyclazole75 WP 375 ga.i/ha and urea $2 \%$ were superior and reducing the population to $1.3,1.5,1.6$, 2.0, 2.1 and 1.8 per hill and registered 87.2, 85.3, 84.3,80.4, 79.4and 82.3 per cent reduction, respectively over control. Sulfoxaflor 3.75 + chlorpyriphos 37.5 SE309 $\mathrm{g}+$ monocrotophos180 ga.i/ha (3.2/hill and $68.6 \%$ reduction), sulfoxaflor $3.75+$ chlorpyriphos 37.5 SE309 g + thiamethoxam 25 WG12.5 ga.i/ha (3.7 /hill and 63.7.\% reduction), sulfoxaflor 3.75 + chlorpyriphos 37.5 SE309 g + quinalphos 25 EC190 ga.i/ha (3.9/hill and $61.8 \%$ reduction), sulfoxaflor 3.75 + chlorpyriphos 37.5 SE $309 \mathrm{~g}+$ carbendazim50 WP $125 \mathrm{~g}$ a.i/ha (4.8/hill and $52.9 \%$ reduction) andsulfoxaflor $3.75+$ chlorpyriphos 37.5 SE309 g+ tricyclazole 190 g a.i/ha (5.1/hill and $50.0 \%$ reduction) were next best treatments. Highest EHB population of 10.2/hill was observed in untreated plot. These results are in accordance with the findings of Insecticide triazophos (20 EC @ $0.02 \%$ ) alone or tank mixed with fungicides carbendazim (50 WP @ $0.05 \%$ ) and tricyclazole (75 WP @ 0.04\%) was effective in controlling WBPH. In none of the cases, combinations of insecticides and fungicides, showed phytotoxic effect on foliage (Prajapati et al., 2005).Ethiprole + imidacloprid when applied alone resulted in significantly lower hopper population (2.8 hoppers/10 hills) followed by combination with fungicides like tricyclazole and hexacaozole (1.5 and 2.0 hoppers/10 hills) compared to rynaxypyr and other treatments (9.0 to 14.3 hoppers/10 hills) (Anon, 2011).

Senthilkumar and Regupathy (2007) studied the compatibility of neonicotinoids (imidacloprid and thiamethoxam) with certain nutrients like urea, di-ammonium phosphate, muriate of potash and fungicides, Bordeaux mixture and propiconazole and reported that the nutrients and fungicides did not hamper the effectiveness of thiamethoxam or imidacloprid.

\section{References}

Anonymous. 2011. Progress report, crop protection (Entomology and Plant pathology), Directorate of rice research. Vol.2:3.121-3.103.

Bhamare, V., D. Wadnerkar, G. Khandagale and Sonawane, Y. 2011. Bio-efficacy of newer insecticidal combinations against sucking pest complex of cotton. World Cotton Research Conference on Technologies for Prosperity Renaissance Convention Centre, Mumbai 7-11 November 2011. Abstract No. 108.

Ghoghari, P.D., Kavad, N.K. and Patil, V.A. 
2019. Evaluation of insecticides against rice gundhi bug, Leptocorisa acuta (Thunberg) in South Gujarat. Journal of Entomology and Zoology Studies. 7(4) 1411-1417.

Lysandrou, M., Ahmad, M. and Longhurst, C. 2012.Comparative efficacy of sulfoxaflor against cotton leafhopper, Amrascadevastans

(Distant)

(Cicadellidae: Homoptera) under field conditions of punjab and sindh. $J$. Agric. Res., 48 (4): 517-524.

Mohanta, P.K., Raju, S.V.S. and Giri, G.S. 2020. Bio-efficacy of certain insecticidal molecules against sucking pests of rice. Journal of Pharmacognosy and Phytochemistry. 9(1): 2107-2113.

Prajapati, K. S., D. M Korat., J. F. Dodia., A. R. Pathak and R. C. Patel. 2005. Field Evaluation of Compatibility of Insecticides and Fungicides on Rice. Pesticides Research Journal, 17(1): 30-32.

Prakash, A., Rao, J., Ghos, S.K. and Gupta, S.P. 1995. Deterioration of grain quality due to bug in eastern India In: IRRI-1995 on fragile lives in fragile ecosystem, 13-18Feb. 1995 at IRRI,
Manila, Philippines. Pp. 22.

Rao, J., and Prakash, A. 1995.Biodegradation of paddy seed quality due to insects and mites and its control using botanicals. Final report ICAR/CRRI Ad-hoc Scheme. Pp.87

Senthilkumar, C.M. and Regupathy, A. 2007. Physical and biological compatibility of neonicotinoids with nutrients and fungicides on pests of coffee. Ann. Pl. Prot. Sci., 15(1): 131-134.

Shahbandeh M. 2019. Statista. (https://www.statista.com/statistics/271 969/world-riceacreage-since-2008/).

Siebert, M.W., James, D., Thomas, P., Steve, P., Nolting, B. and Leonard. R. 2012. Field Evaluations of Sulfoxaflor, a Novel Insecticide, Against Tarnished Plant Bug (Hemiptera: Miridae) in Cotton. The Journal of Cotton Science, 16:129-143.

Tiwari, A., Pandey, J.P., Tripathi, K., Pandey, D., Pandey B. and Shukla, N. 2014. Effectiveness of Insecticides and Biopesticides against Gundhi Bug on Rice Crop in District Rewa (M. P.), India. International Journal of Scientific and Research Publications. 4(1):1-4.

\section{How to cite this article:}

Amsagowri, V. and Muthukrishnan, N. 2021. Evaluation of Pre-Mixture Insecticide, Sulfoxaflor 3.75 + Chlorpyriphos 37.5 SE against Ear Head Bug, Leptocorisa acuta and Combinational Evaluation with Other Insecticides, Fungicides and Urea in Rice. Int.J.Curr.Microbiol.App.Sci. 10(02): 2118-2125. doi: https://doi.org/10.20546/ijcmas.2021.1002.252 